\title{
The Effect of Government Debt on Economic Growth \\ by using VAR Model \\ "The case of Egypt"
}

\author{
Dr. Emam Khalil \\ Lecturer of Economics, \\ Institute of National Planning
}




\begin{abstract}
This Paper discusses the effect Egyptian Debt on the Egyptian GDP through the period of the study from 1980 - 2017. In this project a VAR model is used to describe the dynamics of the Egyptian GDP. We use a model for Debt (General governmental debt) The analysis of the model by means of Granger causality and impulse response functions led to significant model with a high R2, the analysis showed that both lags of GDP and the second lag of Debt only are affecting the GDP.
\end{abstract}




\section{INTRODUCTION}

There are some economic facts of life that emphasize all macroeconomic explanations of growth. Possibly the most significant factor is that, in order to accumulate the capital goods, the consumer goods will have to be foregone at present to generate more units of consumer goods in the future. An increase in the amount of capital goods or capital formation is termed as an investment. For the economic growth to occur the level of investment must be greater than the amount of depreciation, i.e. the quantity by which machines wear out or become outdated during the year.

The greater the intensity of investment over depreciation the larger the prospective output of the economy in the future.

Kitov (2006) suggested that real economic growth (GDP) (Note 1) can be studied using a concept of two-component, economic growth - a deviation or business cycle and an economic trend component. The trend component or economic growth is accountable for the long-term expansion and describes economic efficiency.

The deviation component of economic growth must have a zero-mean value in the long run. Prescott and Hodrick (2003) researched and proposed exogenous shocks as the force driving fluctuations of the real GDP growth rate. Their research during the last 25 years has revealed numerous features of the principal variables involved in the description of the economic development though still many problems still exist in dealing with the theory of economic growth.

Kitov (2005), proposed a GDP growth model that dependent only on the change in a specific age cohort in the population and the attained level of real 
GDP per capita. The model stated that, real GDP per capita has a constant growth increment and the observed fluctuations can be explained by the population component variance. The model has unveiled that in developed countries the real GDP per capita with time, usually grows along with a straight line if no significant change in the specific age population observed in the defined period.

The relative growth rate of GDP can be affected by several factors, some of which show an inverse relationship while other factors show a direct relationship. This paper is devoted to analyzing the extent to which those factors affect GDP growth in developing countries as compared to developing countries.

\section{LITERATURE REVIEW}

A lot of empirical studies support that there is a relationship between debt and economic growth in advanced and emerging economies. According to their empirical results this correlation is particularly strong when debt reaches 100 percent of GDP (for example, Reinhart and Rogoff, 2010; Kuman and Woo, 2010; Checherita and Rother, 2010; Cechetti et al., 2011).

Among the studies that examine the impact of debt on GDP growth, is that of Diamond (1965) which makes an evaluation of the effect of taxes on capital stock, and reaches to the conclusion that the external and internal debt reduces the available lifetime consumption of tax payers as well as their savings, and thus the capital stock. The empirical literature examines the relationship between external debt and debt restructuring on economic growth mostly in developing countries. For developed countries the empirical evidence, particularly for economies belonging to the Euro area, is very 
limited, and most of them examine the impact of fiscal variables (such as government debt, taxes) on long term interest rates and spreads only as an indirect approach affecting economic growth.

The same conclusions derive from the studies of Saint-Paul (1992). There is another set of empirical studies that examine in more detail the impact of different levels of debt on economic growth and find that this negative relationship exists only after a certain debtto-GDP ratio. Smyth and Hsing (1995) indicate that the optimal debt ratio is $38.4 \%$ when debt held by the sector and $48.9 \%$ for total debt. In the same line, Aschauer (2000) examines the relationship between capital and economic growth using data from 48 contiguous U.S. states over the period 1970-1990. The empirical results show whenever the government debt is used to finance productive capital, an increase in debt has a positive effect up to a certain threshold and negative effect beyond it.

Pattillo et al. (2002) using a large panel data set of 93 developing countries for the period 1969-1998, support that the negative impact of external debt on per-capital GDP growth exists only when the net present value of debt levels is above $35 \%-40 \%$ of GDP. In the same line, Clements et al. (2003) based on a panel of 55 low-income countries data over the period 1970-1999, find that the turning point in the net present value of external debt is at $20 \%-25 \%$ of GDP. Schclarek (2004) also finds that the above relationship is particularly strong for several developing countries for the period 1970-2002 and not as strong for industrial countries. Adam and Bevan (2005) examine the impact of fiscal deficit on economic growth for a panel of 45 developing countries. They support that there is a threshold effect at a level of the deficit 
around $1.5 \%$ of GDP. Aizenman et al. (2007) who also find a negative relation between debt and economic growth rate.

Reinhart and Roggof (2010) also study the economic growth and inflation at different levels of government and external debt, based on new data on forty-four countries for the period 1970-2009. Their findings show that the relationship between government debt and real GDP growth is weak for debt/GDP ratios below a threshold of $90 \%$ of GDP. Kumar and Woo (2010) examine the impact of high debt on long-run economic growth, based on a panel of advanced and emerging economies' data for a period of almost four decades. The empirical results suggest that on average, a 10\%-point increase in the initial debt - to GDP ratio is associated with a slowdown in annual real per capital GDP growth of around $0.2 \%$ points per year.

\section{THEORETICAL LITERATURE}

The review of theories on economic growth and debt is outlined below:

\subsection{NEOCLASSICAL GROWTH THEORY}

The neoclassical growth model known as Solow-Swan model predicts that poor countries, characterized as having low initial capital stocks, tend to have high growth rates as they start off well below their steady states, in which their situation allows for a high accumulation of new capital goods. This school of thought stressed that the policy focus should be on increasing rate of savings and investment.

Availability of increased savings spurs additional investments, which fuels economic growth. Due to limited and precarious revenue streams of developing countries, external sources represented a susceptible opportunity to fuel their aspirations for greater investments and growth. 
(Modigliani, 2000), refining contributions by Buchanan (1988) argued that the national debt is a burden for next generations, which comes in the form of a reduced flow of income from a lower stock of private capital.

He considered that a situation in which the gross burden of national debt may be offset in part or in total is when debt finances government expenditure that could contribute to the real income of future generations, such as productive capital formation. (Krugman \& Eggertson, 2012), coins the term of "debt overhang" as a situation in which a country's expected repayment ability on external debt falls below the contractual value of debt. In

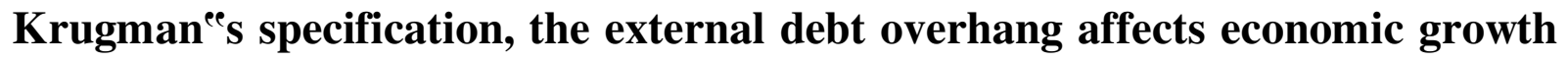
through private investment, as both domestic and foreign investors are deterred from supplying further capital.

The theory implies that debt reduction will lead to increased investment and repayment capacity and, as a result, the portion of the debt outstanding becomes more likely to be repaid. When this effect is strong, the debtor is said to be on the ,wrong side ${ }^{e e}$ side of the debt Laffer curve.

\subsection{TRADITIONAL THEORY OF DEBT}

The theory relies on certain advantages of borrowing. Through debt creation, the government can tap savings streams, put the resources thus raised to productive use and bring about an increase in national income. Keynes however indicated that debt financing should have a limit since much of it may crowd out private investors.

\subsection{CLASSICAL VIEWS ON DEBT}

The new classical (Barro \& Sala-I-Martin, 2003) based his case on Ricardian equivalence theorem (RET) hypothesis of neutrality of debt arguing 
that increase in expenditure which is debt financed would not have effect on the economy as future taxes are personified in the present debt.

He supposed that individuals don't die thus inherit among generations, presence of perfect capital mobility and that individuals can freely borrow and lend in the economy. According to (Malthus, 2013), the existence of the national debt by maintaining a body of unproductive consumers contributed powerfully to distribution and demand. (Malthus, 2013), argued that debt contributed among other things to the evils resulting from changes in the value of money and expressed the desirability of containing the growth of debt. (Mill, 1989), argued that government borrowing was harmful because it destroys capital which could otherwise be used for productive employment. According to (Mill, 1989), it is beneficial to pay-off a debt as early as possible either through immediate payment by a general contribution or by gradual payment from the surplus revenue.

Classical theorist disapproved views of debt because they thought it interfered with the natural order which was conducive to the creation of wealth and increase in the material welfare of the nation. The theory mentioned that Government borrowing makes future financing more difficult by increasing the proportion of the budget which must go for fixed charges and by increasing the amount of taxes which must be paid to finance the interest on the debt.

\section{PROJECT HYPOTHESES}

4.1. H0: There is no any statistically significant relationship between the Gross Domestic Product (GDP) and The General Governmental Debt (GGD)

4.2. H1: There is a statistically significant relationship between the Gross Domestic Product (GDP) and The General Governmental Debt (GGD 


\section{OBJECTIVES OF THE STUDY}

The general objective of the study was to study "the effect of debt in gross domestic product of Egypt".

The specific objective was to:

1) To examine the effect of overdraft from Central Bank on gross domestic product in Egypt.

2) To investigate the effect of external debt on gross domestic product in Egypt.

3) To determine the effect of government securities (Treasury Bills) on gross domestic product.

\section{SIGNIFICANCE OF THE STUDY}

The study will help government and policy makers to know what levels of debt will deter economic growth and thus adopt policies that will keep the country's debt level in a sustainable level. In other words, the study's result will be highly relevant in the formulation and implementation of effective policies. Additionally, policy makers and economists will be able to assess whether the effect on debt is non-linear, that is if the effect on growth depends on the level of debt stock It will also help the government identify and study other variables related to growth including savings and inflation and to what level it should also stop accruing external debt with advice from the policy makers.

\section{SCOPE OF THE STUDY}

The study will ascertain the impact of debt and other macroeconomic variables on the GDP growth in Egypt. It will seek to explore economic growth from broad areas, that is; debt, domestic debt, and external debt. OLS regression model was employed along with descriptive statistics on time series 
data covering the period 1980-2017. This period is more recent and has not been covered by existing literature. Secondly, the period covers three political regimes in Egypt.

\section{DATA:}

To study the effect of governmental debt (GGD) on Gross domestic product (GDP) Figure (1) for the Egyptian economy, the project uses annual data for the period 1980 - 2017. Time series were obtained from world economic outlook (WEOApr2019) for Egypt's gross domestic product (GDP_B) measured in Constant prices and figures is rounded to billions (Appendix 1), Moreover, General Governmental Debt (GGD) data where originally obtained as Percentage to GDP from the International monetary fund data and percentages where transformed to absolute rounded to billions figure from the same GDP data mentioned above Table 1.

\subsection{THE DEPENDENT VARIABLE.}

The growth rate of gross domestic product (GDP). GRGDP is the growth rate of gross domestic product.

\subsection{THE INDEPENDENT VARIABLES.}

* The gross debt (DEBT): DEBT is the general government consolidated gross debt. This variable expresses the impact of debt on GDP growth.

* The gross domestic product (GDP): GDP is the initial level of gross domestic product. This variable shows the impact of the wealth of the economy on GDP growth.

* he gross savings (SAVINGS): SAVINGS is the gross national savings. This variable expresses the highest amount that the economy disposes in order to invest without having to borrow. 
* The exports (Exports): Exports is the sum of exports of goods and services. The imports (Imports). Imports is the sum of imports of goods and services. * The growth rate of trade (GRTRADE): GRTRADE the growth rate of trade of goods and services. We mention that Imports, Exports, Grtrade are considered as control variables because they represent important indicators of the openness of the economy and its external competitiveness, and as such they are used in the relative literature.

* The long-term interest rates (LONG): LONG is the nominal long-term interest rates that is used as a control variable because it captures the impact of inflation.

* The unemployment (UNEMPLOYMENT): UNEMPLOYMENT is the total unemployment rate. This variable is used as a control variable because it expresses the cost of salaries in the economy which is expected to influence the future investments.

* The population (POPULATION): POPULATION is the total population.

* The growth rate of population (GRPOPULATION): GRPOPULATION is the growth rate of total population. The population and the growth rate of population are considered as control variables because they are related to the demographic characteristics of the economy. 
Table 1 descriptive statistics for GDP and GGD

\begin{tabular}{|l|c|c|}
\hline & GDP_B & GGD_B \\
\hline Mean & 1018.190 & 906.0791 \\
\hline Median & $\mathbf{9 0 7 . 2 5 4 5}$ & $\mathbf{7 7 4 . 2 9 3 2}$ \\
\hline Maximum & 1998.300 & 2059.045 \\
\hline Minimum & 387.2330 & 448.1909 \\
\hline Std. Dev. & 485.0302 & 388.7792 \\
\hline Skewness & $\mathbf{0 . 5 2 7 2 6 7}$ & 1.219674 \\
\hline Kurtosis & 1.984405 & 4.010534 \\
\hline Sum & 38691.23 & 34431.01 \\
\hline Sum Sq. Dev. & $\mathbf{8 7 0 4 4 0 8 .}$ & $\mathbf{5 5 9 2 5 2 4}$ \\
\hline Observations & 38 & 38 \\
\hline
\end{tabular}

GDP_B

2,400

2,000

1,600

1,200

800

400

0

19801985199019952000200520102015

2,400

2,000

1,600

1,200

800

400

1980198519901995200020052010,2015

Figure 1 "Data representation" 


\section{ECONOMETRIC ANALYSIS}

The economic literature examines the impact of general governmental debt on GDP growth and concludes that debt has an impact on economic growth. This idea is supported by the results of many empirical studies that have proven the above relationship in advanced and emerging economies (see for example, Diamond, 1965; SaintPaul, 1992; Schclarek, 2004; Adam and Bevan, 2005; Aizenman et al., 2007).

So, to study the Impact of general governmental debt on the GDP we can express the general governmental debt as a function of the gross domestic product.

Gross Domestic Product $=$ F (General Governmental Debt)

Also, General governmental debt can be expressed as a function of Gross domestic product.

General Governmental Debt $=$ F (Gross Domestic Product)

\subsection{Unit Root Tests}

In order to avoid spurious regression, the variables should be tested for nonstationarity. In the project, augmented dickey fuller unit root test is implemented to test whether each variable is stationary or not,

$\Delta y t=\beta 1+\beta 2 t+\delta y t-1+\Sigma \alpha \Delta y t-i+u t$

$m$

$i=1$

Where: $y t$ is the variable under consideration, $t$ is a time trend, $u t$ is the error term.

The coefficient of the variable is tested whether it is equal to zero (i.e. $\delta=0$ ). So, the hypothesis of this test.

$H 0: \delta=0$ (unit root exists, and the series is non-stationary)

$H 1: \delta \neq 0$ (the series is stationary)

After using the augmented dickey fuller unit root test, order of integration can be determined. The order represents the differenced " $d$ " times to make a nonstationary time series a stationary one. 
GDP has a trend, so the Unit root was done, and it was not stationary on level Appendix (2) and stationary of order one Table (2)

Null Hypothesis: D(GDP_B) has a unit root

Exogenous: Constant, Linear Trend

Lag Length: 3 (Automatic - based on SIC, maxlag=9)

\begin{tabular}{ccc}
\hline \hline & t-Statistic & Prob.* \\
\hline Augmented Dickey-Fuller test statistic & -4.820208 & $\mathbf{0 . 0 0 2 5}$ \\
\hline Test critical values: $1 \%$ level & -4.262735 & \\
$5 \%$ level & -3.552973 & \\
$10 \%$ level & -3.209642 & \\
\hline
\end{tabular}

*MacKinnon (1996) one-sided p-values.

Table 2 Unit root test Source "authors calculations"

GGD has a trend, so the Unit root was done, and it was not stationary on

level Appendix (3) and stationary of order one Table (3)

Null Hypothesis: D(GGD_B) has a unit root

Exogenous: Constant, Linear Trend

Lag Length: 0 (Automatic - based on SIC, maxlag=9)

\begin{tabular}{|c|c|c|}
\hline & t-Statistic & Prob.* \\
\hline $\begin{array}{c}\text { Augmented Dickey-Fuller test } \\
\text { statistic }\end{array}$ & -3.808742 & 0.0276 \\
\hline Test critical values: $1 \%$ level & -4.234972 & \\
\hline $5 \%$ level & -3.540328 & \\
\hline $10 \%$ level & -3.202445 & \\
\hline
\end{tabular}

*MacKinnon (1996) one-sided p-values.

Table 3: Unit root test. Source: "authors calculations" 


\subsection{Cointegration Tests}

In order to assess if the two series has a cointegration and thus and Error Correction model can best fit the long run relationship between GDP and GGD (since they are already integrated of order one) a Johansen Cointegration test was performed as follow Table (4):

Sample (adjusted): 19832017

Included observations: 35 after adjustments

Trend assumption: Linear deterministic trend (restricted)

Series: GDP_B GGD_B

Lags interval (in first differences): 1 to 2

Unrestricted Cointegration Rank Test (Trace)

\begin{tabular}{|c|c|c|c|c|}
\hline $\begin{array}{c}\text { Hypothesized } \\
\text { No. of CE(s) }\end{array}$ & Eigenvalue & $\begin{array}{c}\text { Trace } \\
\text { Statistic }\end{array}$ & $\begin{array}{c}0.05 \\
\text { Critical Value }\end{array}$ & Prob.** \\
\hline None $*$ & 0.392303 & 28.89471 & 25.87211 & 0.0204 \\
\hline At most 1 & 0.279265 & 11.46193 & 12.51798 & 0.0746 \\
\hline
\end{tabular}

Trace test indicates 1 cointegrating eqn(s) at the 0.05 level

denotes rejection of the hypothesis at the 0.05 level **MacKinnon-Haug-Michelis (1999) p-values.

Table 4: Johansen Cointegration test. Source:"authors calculations"

The Trace Test Result showed a significance of at None and therefore the test indicates one co integration equations between the two series however, the coefficient of the regression between Error (-1) and D(GDP_B) "The Error Correction Term" is not negative Table (5) and thus the model will not correct itself on the long-run and VECM will not be used to estimate this relationship and this is also supported by testing the Linear Regression residuals between the two variables (Appendix 4)

Dependent Variable: D(GDP_B)

Method: Least Squares 
Sample (adjusted): 19812017

Included observations: 37 after adjustments

\begin{tabular}{ccccc}
\hline \hline Variable & Coefficient & Std. Error & t-Statistic & Prob. \\
\hline \hline ERRORLR (-1) & $\mathbf{0 . 0 4 6 0 8 5}$ & $\mathbf{0 . 0 2 1 8 8 3}$ & $\mathbf{2 . 1 0 5 9 4 9}$ & $\mathbf{0 . 0 4 2 5}$ \\
C & $\mathbf{4 3 . 1 0 3 6 7}$ & $\mathbf{3 . 7 9 4 8 3 5}$ & $\mathbf{1 1 . 3 5 8 5 1}$ & $\mathbf{0 . 0 0 0 0}$ \\
\hline \hline
\end{tabular}

Table 5 Liner regression D(GDP_B) and Error (-1).

Source: "authors calculations".

\subsection{Granger causality}

Granger causality is a statistical concept of causality that is based on prediction. According to Granger causality, if a signal X1 "Granger-causes" (or "G-causes") a signal X2, then past values of X1 should contain information that helps predict $\mathrm{X} 2$ above and beyond the information contained in past values of X2 alone. Its mathematical formulation is based on linear regression modeling of stochastic processes (Granger 1969) Table (6).

Pairwise Granger Causality Tests

Sample: 19802017

Lags: 2

\begin{tabular}{cccc}
\hline \hline Null Hypothesis: & Obs & \multicolumn{2}{c}{ F-Statistic Prob. } \\
\hline \hline $\begin{array}{c}\text { GGD_B does not Granger Cause } \\
\text { GDP_B }\end{array}$ & 36 & 4.96371 & $\mathbf{0 . 0 1 3 5}$ \\
$\begin{array}{c}\text { GDP_B does not Granger Cause } \\
\text { GGD_B }\end{array}$ & & 2.76991 & $\mathbf{0 . 0 7 8 2}$ \\
\hline \hline
\end{tabular}

Table 6 Granger causality tests Source "authors calculations"

The ganger causality test showed that GGD is a granger cause of GDP, but the GDP is not a granger cause of GGD. 


\subsection{Vector Autoregressive analysis}

VAR is a system of dynamic equations contains several endogenous variables together. Each endogenous variable is explained by its lagged values and the lagged values of all other endogenous variables in the system.

Assuming (k) endogenous variables (X) and (b) exogenous variables (Z), VAR model can be written as (Wooldridge,2009):
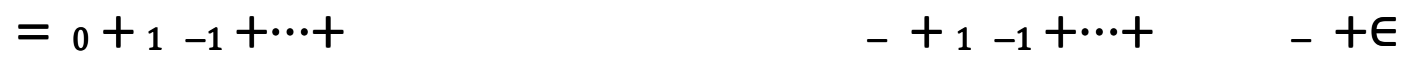

Where:
- $\quad$ p:is the number of lags for endogenous variables.
- $\quad$ : $\quad$ is the number of lags for exogenous variables
- : is a $\mathrm{k}^{*} \mathbf{1}$ matrix of constants,
- $\quad$... : are $k * k$ matrices of parameters,
- $\quad \ldots \quad-$ : are $k^{* 1} 1$ endogenous variables vector,
- $\quad \ldots$ : are $k * b$ matrices of parameters
- $\quad \ldots \quad-$ : $\quad$ are $b^{* 1} 1$ exogenous variables vector,
- $\quad \epsilon_{\mathrm{t}}$ is assumed to be white noise that is, error has zero expected value given past

Information on $X$ and $Z$ (Wooldridge,2009). Also, $\epsilon_{\mathrm{t}}$ are the stochastic error terms, called impulses or innovations or shocks in the language of VAR. (Gujarati,2004)

The next step is studying the short run dynamics of the hypothesized relations using VAR analysis. The unrestricted VAR is run with the variable as endogenous and the appropriate number of lags is selected according to the lag selection criteria Table (7). 
VAR Lag Order Selection Criteria

Endogenous variables: GDP_B GGD_B

Exogenous variables: C

Sample: 19802017

Included observations: 35

\begin{tabular}{|c|c|c|c|c|c|c|}
\hline Lag & $\log L$ & LR & FPE & AIC & SC & HQ \\
\hline 0 & -489.4029 & NA & $5.37 e+09$ & 28.08017 & 28.16904 & 28.11085 \\
\hline 1 & -348.1923 & 258.2136 & 2115180. & 20.23956 & 20.50619 & 20.33160 \\
\hline 2 & -332.1879 & 27.43624* & 1068507.* & $19.55359 *$ & * 19.99798* & 19.70699* \\
\hline 3 & -329.9401 & 3.596357 & 1189326. & 19.65372 & 20.27586 & 19.86848 \\
\hline
\end{tabular}

Table 7 Lag Length Criteria Source "authors calculations"

The appropriate number of lags selected for the model is two lags as indicated by most criteria.

Estimating the relationship between GDP and GGD is to be a one-way relationship as per the result of the Granger Causality test so the Var model (Appendix 5,6) equation will be as follow

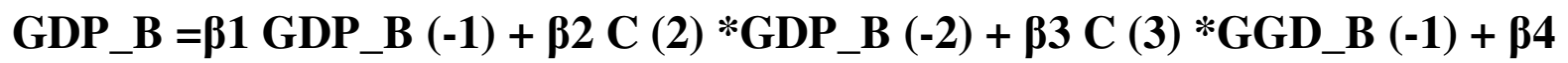
*GGD_B (-2) + C

The Result of model estimation Table (8) where:

Dependent Variable: GDP_B

Method: Least Squares (Gauss-Newton / Marquardt steps)

Sample (adjusted): 19822017

Included observations: 36 after adjustments

GDP_B = C (1) *GDP_B (-1) + C (2) *GDP_B (-2) + C (3) *GGD_B (-1) + C (4)

*GGD_B (-2) + C (5) 


\begin{tabular}{ccccc}
\hline & Coefficient & Std. Error & t-Statistic & Prob. \\
\hline \hline C (1) & $\mathbf{1 . 6 0 5 6 7 7}$ & $\mathbf{0 . 1 2 9 4 3 3}$ & $\mathbf{1 2 . 4 0 5 4 5}$ & $\mathbf{0 . 0 0 0 0}$ \\
C (2) & $\mathbf{- 0 . 6 2 5 1 4 7}$ & $\mathbf{0 . 1 3 5 5 4 7}$ & $\mathbf{- 4 . 6 1 2 0 4 2}$ & $\mathbf{0 . 0 0 0 1}$ \\
C (3) & $\mathbf{- 0 . 0 2 4 7 9 7}$ & $\mathbf{0 . 0 3 0 2 7 5}$ & $\mathbf{- 0 . 8 1 9 0 4 7}$ & $\mathbf{0 . 4 1 9 0}$ \\
C (4) & $\mathbf{0 . 0 7 9 5 4 8}$ & $\mathbf{0 . 0 3 3 4 3 7}$ & $\mathbf{2 . 3 7 9 0 1 3}$ & $\mathbf{0 . 0 2 3 7}$ \\
C (5) & $\mathbf{- 7 . 8 6 9 8 0 3}$ & $\mathbf{6 . 6 6 9 4 4 7}$ & $\mathbf{- 1 . 1 7 9 9 7 8}$ & $\mathbf{0 . 2 4 7 0}$ \\
\hline \hline R-squared & $\mathbf{0 . 9 9 9 3 9 0}$ & Mean dependent var & $\mathbf{1 0 5 3 . 0 0 7}$ \\
Adjusted R- & & & \\
squared & $\mathbf{0 . 9 9 9 3 1 1}$ & S.D. dependent var & $\mathbf{4 7 4 . 3 4 8 4}$ \\
S.E. of regression & $\mathbf{1 2 . 4 5 3 2 1}$ & Akaike info criterion & $\mathbf{8 . 0 1 0 0 8 0}$ \\
Sum squared & & & & \\
resid & $\mathbf{4 8 0 7 . 5 5 7}$ & Schwarz criterion & $\mathbf{8 . 2 3 0 0 1 4}$ \\
Log likelihood & $\mathbf{- 1 3 9 . 1 8 1 4}$ & Hannan-Quinn criter. & $\mathbf{8 . 0 8 6 8 4 3}$ \\
F-statistic & $\mathbf{1 2 6 8 7 . 4 7}$ & Durbin-Watson stat & $\mathbf{2 . 1 6 6 5 8 3}$ \\
Prob(F-statistic) & $\mathbf{0 . 0 0 0 0 0 0}$ & & & \\
\hline
\end{tabular}

Table 8 Model estimation Source "authors estimates"

The Var estimation showed a significant model with a significant effect between the GDP and its own first and second lags and the second lag of the GGD and final Var equation Substituted Coefficients were:

GDP_B $=1.6056765599 * G D P \_B(-1)$ - 0.625147228975 $*$ GDP_B (-2) -

0.0247966319911*GGD_B $\quad(-1) \quad+\quad 0.0795475346243 * G G D \_B \quad(-2) \quad-$

\subsection{4}

9.5. Impulse response functions (IRFs)

Another tool of analysis for the VAR model is plotting the impulse response functions Figure (2).

It indicates the response of a variable to a one standard deviation shock of innovations (impulse variable) in another variable (response variable).

The IRFs of interest to this project will be discussed as follows: 
From the GDP model, the interest is focused on the response of GDP to unexpected changes in General Governmental debt. So, the studied IRFs are those of (GGD) on (GDP).

The below figures (second and third) show the response of the GDP variable (GDP_B) to a one standard deviation shock of innovations in the General Governmental debt variable.

(GGD_B) and also show the response of the General Governmental debt variable (GGD_B) to a one standard deviation shock of innovations in the GDP variable (GDP_B). Both indicate an insignificant response to the shock at the 5\% significance level as the confidence interval (red boundaries) include Zero.

Response to Cholesky One S.D. (d.f. adjusted) Innovations \pm 2 S.E.

Response of GDP_B to GDP_B

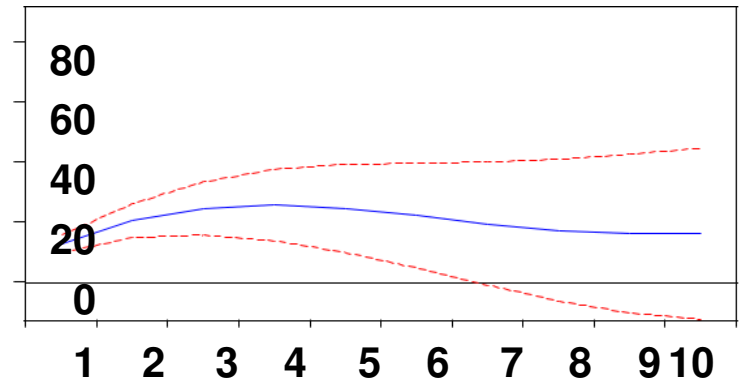

Response of GGD_B to GDP_B

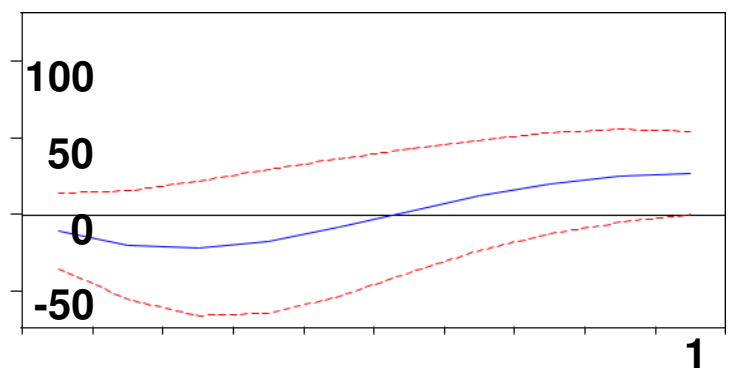

$\begin{array}{llllllllll}1 & 2 & 3 & 4 & 5 & 6 & 7 & 8 & 9 & 0\end{array}$
Response of GDP_B to GGD_B

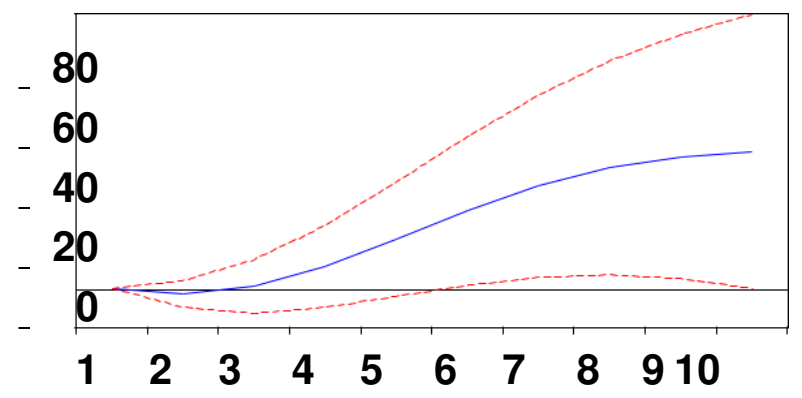

Respons e of GGD_B to GGD_B

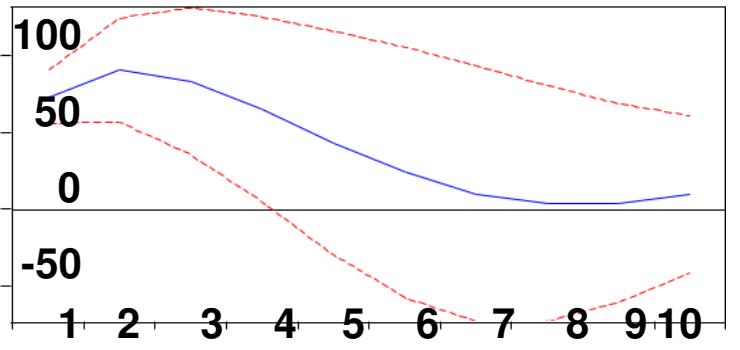

Figure 2 Impulse Function Source "authors calculations" 


\subsection{Model Diagnostics}

Model Diagnostics is a set of procedures available for regression analysis that seek to assess the validity of a model in any of several different ways and is an essential part in order to validate whether the statistical model is also an econometric model these procedures include Serial Correlation LM Test, Heteroskedasticity Test: White, Residuals ACF and PACF, Normality test, and Recursive estimates for model stability.

\subsubsection{Serial Correlation LM Test}

Serial correlation (also called Autocorrelation) is where error terms in a time series transfer from one period to another. In other words, the error for one time period a is correlated with the error for a subsequent time period $b$. For example, an underestimate for one quarter's profits can result in an underestimate of profits for subsequent quarters Breusch-Godfrey Serial Correlation LM Test Table (9) was performed (VAR LM test appendix 8) to assess the autocorrelation of the model and the results were as follow: 
Breusch-Godfrey Serial Correlation LM Test:

\begin{tabular}{lll}
\hline \hline F-statistic & 1.987163Prob. F $(2,29)$ & 0.1553 \\
Obs*R-squared & 4.339004Prob. Chi-Square (2) & $\mathbf{0 . 1 1 4 2}$ \\
\hline \hline
\end{tabular}

Test Equation:

Dependent Variable: RESID

Method: Least Squares

Sample: 19822017

Included observations: 36

Presample missing value lagged residuals set to zero.

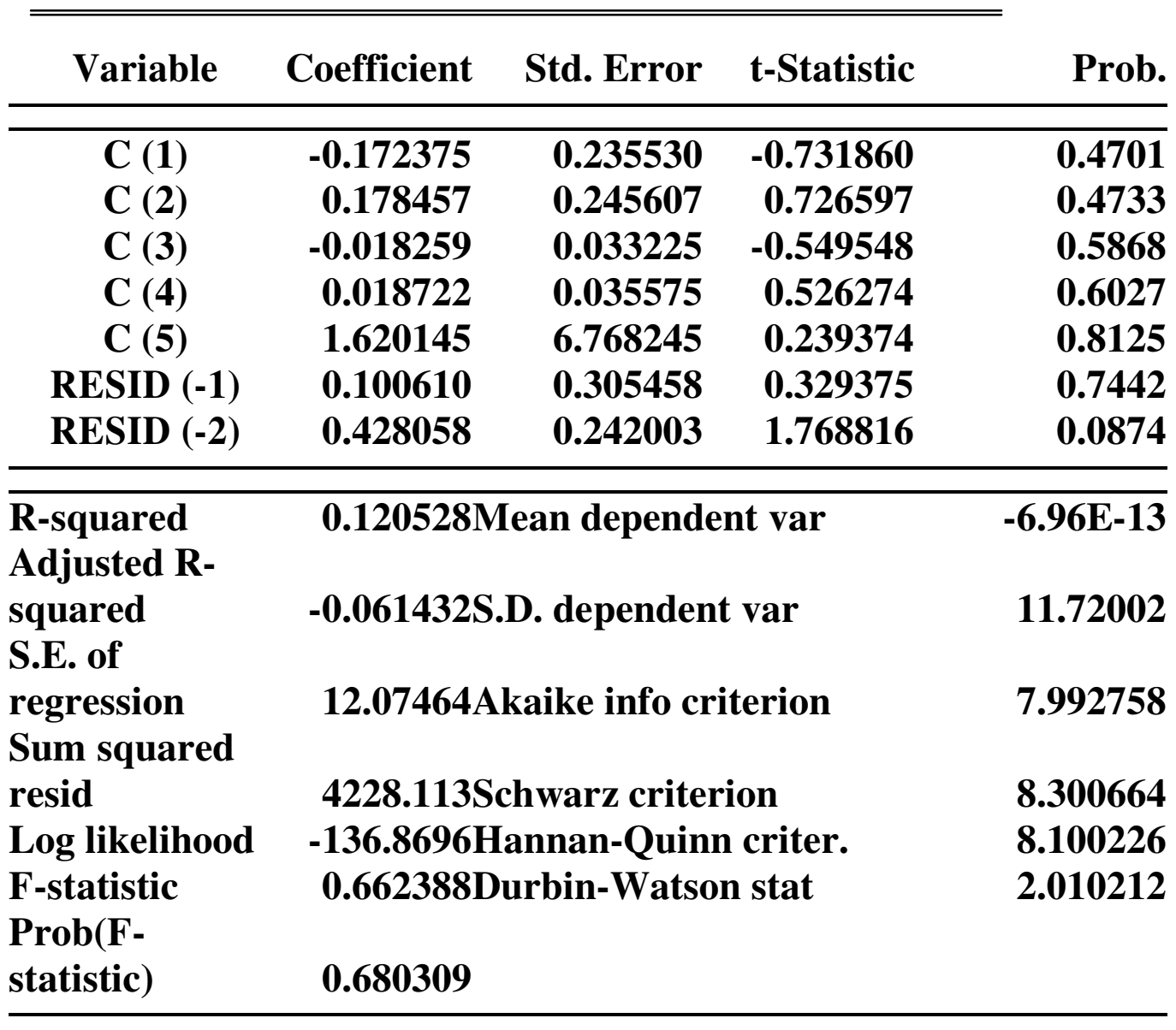

Table 9 Breusch-Godfrey test Source "authors calculations" 
The test showed no serial correlation problem in the model as the Chi-Square (2) $>0.05$

\subsubsection{Heteroskedasticity Test:}

In statistics, heteroskedasticity (or heteroscedasticity) happens when the standard errors of a variable, monitored over a specific amount of time, are non-constant. With heteroskedasticity, the tell-tale sign upon visual inspection of the residual errors is that they will tend to fan out over time

White Heteroskedasticity Test was performed Table (10) (VAR Heteroskedasticity test appendix 7) to assess the Heteroskedasticity of the model and the results were as follow:

Heteroskedasticity Test: White

\begin{tabular}{|c|c|c|}
\hline F-statistic & 2.523299 & $\begin{array}{r}\text { Prob. F } \\
(\mathbf{1 4 , 2 1})\end{array}$ \\
\hline Obs*R-squared & 22.57818 & Prob. Chi-Square (14) \\
\hline caled explained SS & 30.00958 & Prob. Chi-Square (14) \\
\hline
\end{tabular}

Test Equation:

Dependent Variable:

RESID $^{\wedge} 2$

Method: Least Squares

Sample: 19822017

Included observations: 36

\begin{tabular}{|c|c|c|c|c|}
\hline Variable & $\begin{array}{c}\text { Coefficie } \\
\text { nt }\end{array}$ & Std. Error & t-Statistic & Prob. \\
\hline $\mathbf{C}$ & -592.7537 & 530.0288 & -1.118342 & 0.2761 \\
\hline$(\text { GDP_B }(-1))^{\wedge} 2$ & -0.212914 & 0.223574 & -0.952318 & 0.3518 \\
\hline$($ GDP_B $(-1)) *\left(G D P \_B(-2)\right)$ & 0.452521 & 0.462366 & 0.978707 & 0.3389 \\
\hline$($ GDP_B $(-1)) *\left(G G D \_B(-1)\right)$ & 0.100353 & 0.094924 & 1.057187 & 0.3024 \\
\hline$($ GDP_B $(-1)) *\left(G G D \_B(-2)\right)$ & -0.095300 & 0.093995 & -1.013886 & 0.3222 \\
\hline GDP_B $(-1)$ & -11.31103 & 11.43136 & -0.989474 & 0.3337 \\
\hline$\left(G D P \_B(-2)\right)^{\wedge} 2$ & -0.238649 & 0.237544 & -1.004651 & 0.3265 \\
\hline
\end{tabular}




\begin{tabular}{|c|c|c|c|c|}
\hline GGD B (-1)) & & & & \\
\hline$($ GDP_B $(-2)) *($ GGD_B $(-2))$ & 0.104895 & 0.099848 & 1.050550 & 0.3054 \\
\hline GDP_B $(-2)$ & 9.680307 & 11.37322 & 0.851149 & 0.4043 \\
\hline$(\text { GGD_B }(-1))^{\wedge} 2$ & 0.005235 & 0.006460 & 0.810340 & 0.4268 \\
\hline$($ GGD_B $(-1)) *($ GGD_B $(-2))$ & -0.006775 & 0.013758 & -0.492487 & 0.6275 \\
\hline GGD_B (-1) & 2.183225 & 1.906286 & 1.145277 & 0.2650 \\
\hline$\left(G G D \_B(-2)\right)^{\wedge} 2$ & -0.000548 & 0.007528 & -0.072771 & 0.9427 \\
\hline GGD_B (-2) & 1.593044 & 2.879757 & 0.553187 & 0.5860 \\
\hline & & Mean & & \\
\hline R-squared & 0.627172 & $\begin{array}{c}\text { var } \\
\text { S.D. } \\
\text { dependent }\end{array}$ & & 133.5433 \\
\hline Adjusted R-squared & 0.378619 & var & & 256.4369 \\
\hline S.E. of regression & 202.1433 & Akaike inf & criterion & 13.75017 \\
\hline Sum squared resid & 858100.4 & $\begin{array}{l}\text { Schwarz } \\
\text { criterion }\end{array}$ & & 14.40997 \\
\hline Log likelihood & -232.5030 & Hannan-Qu & inn criter. & 13.98046 \\
\hline F-statistic & 2.523299 & $\begin{array}{c}\text { Durbin- } \\
\text { Watson stat }\end{array}$ & & 2.259917 \\
\hline Prob(F-statistic) & 0.026956 & & & \\
\hline
\end{tabular}

Table 10 Heteroskedasticity Test: White Source "authors calculations"

The test showed NO Heteroskedasticity problem in the model as the ChiSquare (2) $>0.05$

Normality Test:

Normality tests are used to determine if a data set is well-modeled by a normal distribution and to compute how likely it is for a random variable underlying the data set to be normally distributed.

Jarque-Bera test Table (11) was performed (VAR Normality test appendix 9) as a goodness-of-fit test of whether sample data have the skewness and kurtosis 
matching a normal distribution. The test statistic should always be a nonnegative result. and the results were as follow:

\begin{tabular}{cccc}
$\begin{array}{c}\text { Compone } \\
\text { nt }\end{array}$ & Jarque-Bera df & Prob. \\
\hline 1 & 5.046456 & 2 & 0.0802
\end{tabular}

Table 11 Jarque-Bera test Source "authors calculations"

The test showed the residuals in the model follows normal distribution as

Jarque-Bera prob. $>0.05$ Appendix (10)

9.6.3. Residuals ACF and PACF:

Autocorrelation and partial autocorrelation are measures of association between current and past series values and indicate which past series values are most useful in predicting future values.

- Autocorrelation function (ACF) Figure (3). At lag k, this is the correlation between series values that are $k$ intervals apart.

Partial autocorrelation function (PACF) Figure (3). At lag k, this is the correlation between series values that are $k$ intervals apart

ACF and PACF were done for Residuals to assess if there is any autocorrelation between the residuals and the result was as follows: 
Sample: 19802017

Included observations: 36

Q-statistic probabilities adjusted for 2 dynamic regressors

\begin{tabular}{|c|c|c|c|c|c|c|}
\hline Autocorrelation & Partialc & rele & tion & $\overline{A C}$ & PACQ-Stat & Prob* \\
\hline & & & 1 & -0.114 & -0.1140 .5105 & 0.475 \\
\hline & & 1 & 2 & 0.308 & 0.2994.3381 & 0.114 \\
\hline & & 1 & 3 & -0.085 & -0.0294 .6354 & 0.201 \\
\hline & & $\mid$ & 4 & -0.058 & -0.1774 .7800 & 0.311 \\
\hline 11 & 1 & 1 & 5 & -0.139 & -0.1405 .6350 & 0.343 \\
\hline $1 \mid$ & & 1 & 6 & 0.078 & 0.1495 .9134 & 0.433 \\
\hline & & 1 & 7 & -0.045 & 0.0596.0081 & 0.539 \\
\hline & & 1 & 8 & 0.068 & -0.0366 .2316 & 0.621 \\
\hline & & | & 9 & -0.051 & -0.0966 .3656 & 0.703 \\
\hline $11 \mid$ & $1 \mid$ & 1 & 10 & -0.038 & -0.0626 .4433 & 0.777 \\
\hline $\mid$ & & 1 & 11 & -0.205 & -0.1708 .7328 & 0.647 \\
\hline & & I & 12 & -0.166 & -0.20610 .297 & 0.590 \\
\hline $\begin{array}{ll}1 & \mathbb{1} \mid \\
\mathbf{t} & \end{array}$ & i & 1 & 13 & -0.179 & -0.13412 .203 & 0.511 \\
\hline$\left.$\begin{tabular}{ll|}
1 & $\mathbb{\pi}$ \\
& $\mathbb{I}$
\end{tabular}\right|$^{\prime}$ & 'I & | & 14 & -0.164 & -0.16013 .866 & 0.460 \\
\hline , 吕 & , 믐, & $\mid$ & 15 & 0.100 & 0.10614 .521 & 0.486 \\
\hline $\mid$ & | 吕 & & 16 & 0.009 & 0.04614 .526 & 0.560 \\
\hline
\end{tabular}

*Probabilities may not be valid for this equation specification.

Figure 3 ACF and PACF

Source "authors calculations" 
The ACF and PACD showed the residuals in the model has no any autocorrelation as all the result sustained between the boundaries.

9.6.4. Recursive estimates for model stability:

Recursive estimates for model stability is how well the results of the study or experiment hold up, statistically speaking. More specifically, it's a measure of how well the control for random errors in the study is. Ways to ensure statistical stability include using p-values or confidence intervals

Recursive Bayesian estimation Figure (4) was performed (also known as a Bayes filter, is a general probabilistic approach for estimating an unknown probability density function recursively over time using incoming measurements and a mathematical process model) to assess the model stability and the result were as follow:

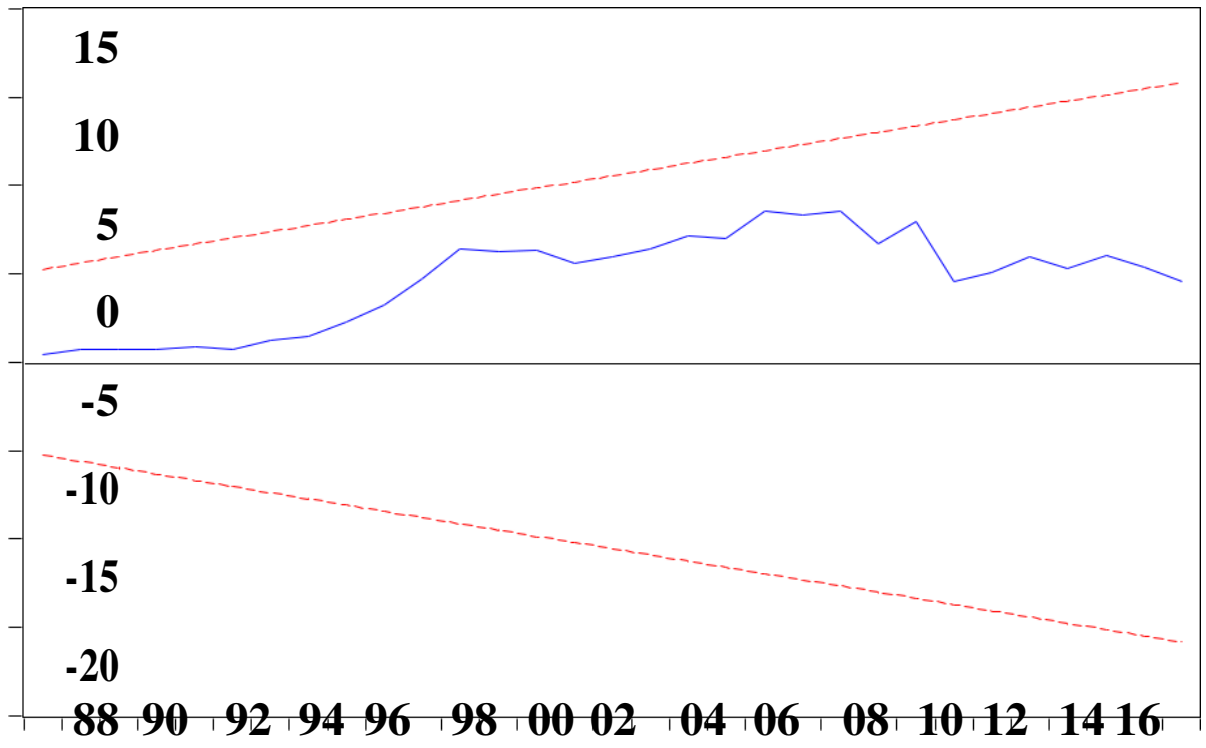

CUSUM 5\% Significan

Figure 4 Recursive estimates Source

"authors calculations" 
The test showed the model is stable as the model estimations maintain between the two boundaries under a $5 \%$ confidence interval.

\section{CONCLUSION}

The project aimed to study the effect of General Governmental debt on Gross Domestic Product, A separate vector autoregressive (VAR) model was formed for Gross domestic product. Granger causality tests and Impulse response functions were used to analyze each VAR model. Regarding the main interest of the project, the analysis showed significant effect of General Governmental debt on Gross Domestic Product. These results show that Egyptian debt is has a positive relationship on the GDP however the GDP is not affecting the Governmental debt.

The actual model is:

GDP_B = C (1) *GDP_B (-1) + C (2) *GDP_B (-2) + C (3) *GGD_B (-1) + C (4) *GGD_B (-2) + C (5)

And thus, we will reject $\mathrm{HO}$ and accept $\mathrm{H1}$ : There is a statistically significant relationship between the Gross Domestic Product (GDP) and The General Governmental Debt (GGD) as there is a positive relationship between the second lag GGD and the GDP.

\section{RECOMMENDATIONS}

Following the conclusions drawn above from the study, it is recommended that the government should reduce reliance on external debt as the effect of it on GDP growth is very week and thus increasing the GDP growth by maximizing tax revenue collection to finance both recurrent and capital expenditure. If the government must borrow, then it should negotiate for concessionary rates and longer repayment period. 
This would effectively reduce the tax burden even for future generations. On the other hand, domestic borrowing can be increased to finance growth enhancing investments. Where capital investments are to be financed through foreign debt, they should be vetted, and a cost benefit analysis done to ascertain their economic benefit to the taxpayer expenditure on key infrastructural projects should be encouraged as this stimulates economic performance.

Further research needs to be conducted to determine other macroeconomic variables that determine economic performance in Egypt. An area for further research would be determine the threshold level of debt beyond which it begins to adversely affect GDP or the maximum level of debt that can still spur economic performance. 


\section{BIBLIOGRAPHY}

[1]. Abu Bakar, N., \& Hassan, S. (2008). Empirical Evaluation on External Debt of Malaysia. International Business\& Economics Research Journal, 1-30.

[2]. Afxentiou, P. C., \& Serletis, A. (1996). Growth and foreign indebtedness in developing countries: An empirical study using long term cross-country data. J. Dev. Areas, 31(1): 25-40. Journal of Development Economics, 31(1), 25-40.

[3]. Augustor et al. (2015). Debt and Economic Growth. Journal of Economics, 25-28. Babu et al. (2014). External debt and economic growth in the East Africa Community. Africa Journal of Business Management, 10111018.

[4]. Barro, R., \& Sala-i-Martin, X. (2003). Economic Growth (Ed ed.). New York: McGraw Hill.Beck, T., Levine, R., \& Loyaza, N. (2000). Finance and the Sources of Growth. Journal of Financial Economics, 58, 261-300.

[5]. Benhabib, J., \& Spiegel, M. M. (2000). The Role of Financial Development in Growth and Investment. Journal of Economic Growth, 25-35.

[6]. Blake, T. (2015). Investigating the Impact of Debt on Economic Growth in Jamaica. Kingston: Bank of Jamaica.

[7]. Blinder, A. S. (2012). The Concise Encyclopedia of Economics. Keynesian Economics.

[8]. Buchanan, J. M. (1999). Liberty Fund. Retrieved from ISBN-o-86597216-8.

[9]. Burguet, S., \& Ruiz, J. (1998). Growth through taxes and borrowing? A model of development traps with capital. European Journal of political Economy, 327-344.

[10]. Central Bank of Egypt. (2014). Central Bank of Egypt Act. Egypt: Central Bank of Egypt.

[11]. Creswell, J. W. (2003). Research Design: Qualitative, Quantitative and Mixed Methods Approaches. Washington: Sage.

[12]. Cunningham, R. T. (1993). The effects of debt burden on economic growth in heavily indebted Nations. Journal of Economics Development, 115126. 
[13]. De Bondt, G. (2002). Euro area corporate debt securities market: First empirical evidence. Working Paper No. 164 (pp. 16-24). Frankfurt: European Central Bank Working Paper Series.

[14]. Deshpande, A. (1997). The debt overhang and the disincentive to invest. Journal of Development Economics, 52, 169-187.

[15]. Dimitrova, N. (2005). Stability Analysis of a Nonlinear Model of Wastewater Treatment Processes. In L. V. Zhilin Li, Numerical

Analysis and Its Applications (pp. 598-604). Rousse: NAA. Effect of Debt on the Gross

Domestic Product in Egypt DOI: 10.9790/5933-0706015972 www.iosrjournals.org 70 | Page

[16]. Goosen, F. M. (2013). Institutional Aspects of Economic Growth: Assessing the Significance of Debt, Economic Governance and Industrial Competition, The Open Business Journal.

[17]. Granger, C. W., \& Newbold, P. (1974). Spurious Regressions in Econometrics. Journal of Econometrics, 2, 111-120.

[18]. Hameed, H. A., \& Chaudhary, M. A. (2008). External Debt and Its Impact on Economic and Business Growth in Pakistan. International Research Journal of Finance and Economics, 20, 132-140.

[19]. Himbara, D. (1993). Myths and Realities of Egyptian Capitalism. Journal of African Political Economy, 93-107.

[20]. International Monetary Fund. (2009). Fighting the Global Crisis. Istanbul: IMF publication Services.

[21]. Krugman, P., \& Eggertson, G. P. (2012). Debt, Deleveraging, and the Liquidity Trap: A Fisher-Minsky-Koo Approach. The Quarterly Journal of Economics, 127(3), 1469-1513.

[22]. Maana, I., Owin, R., \& Mutai, N. (2008). Domestic Debt and its Impact on the Economy-The case of Egypt. 13th Annual African Econometric Society Conference (pp. 1-27). Pretoria: Econometric Society.

[23]. Mageto, J. N. (2015, May 10). Debt and Economic Growth in Egypt. Debt and Economic Growth in Egypt. Nairobi, Nairobi, Egypt: Egyptian University.

[24]. Makau, J. A. (2008). External Debt Servicing and Economic Growth in Egypt. An Empirical Analysis. University of Nairobi.

[25]. Malthus. (2013). Classical Economics (II). In R. B. Ekelund, \& R. F. Hebert, A History of economic Theory and Method (pp. 181-183). Illionois: Waveland Press Inc, 
[26]. Matiti, C. (2013). The Relationship Between Debt and Economic Growth in Egypt. International Journal of Social Sciences and Project Planning Management, 65-86.

[27]. Maysami, R. C., Howe, L. C., \& Hamzah, M. A. (2011). Relationship between macroeconomic variables and stock market indices: cointegration evidence from stock exchange of Singapore. UKM Journal Article Repository, 47-77.

[28]. Mill, J. S. (1989). Principles of political Economy (46 ed.). London: Longmans, Green and Co.

[29]. Modigliani. (2000, January 15). National Debt in a Neoclassical Growth Model. The American Economic Review, pp. 1124-1152.

[30]. Neusser, K., \& Kugler, M. (1998). Manufacturing Growth and Financial Development: Evidence from OECD Countries. The Review of Economic and Statistics, 638-646.

[31]. Ngechu, M. (2004). Understanding the research process and methods: An introduction to Research. Nairobi: Egypt Literature

Bureau.

[32]. Onyango, J. K. (2014, June 12). The Impact of External Debt on Economic Growth in Egypt. The Impact of External Debt on Economic Growth in Egypt. Nairobi, Nairobi, Egypt: http://erepository.uonbi.ac.ke.

[33]. Panizza, U., \& Presbitero, A. F. (2013, January 10). Debt and Economic Growth in Advanced Economies., pp. 1 -24. Working paper no. 78, pp. 1-24.

[34]. Patenio, J. S., \& Tan-Cruz, A. (2007). Economic Growth and External Debt Servicing. 10th National Convention on Statistics (NCS). Manila: National Convention on Statistics.

[35]. Pesaran et al. (2001). Bounds testing approaches to the analysis of level of relationships. Journal of Applied Economics, 16(3), 289-326.

[36]. Rifaqat, A., \& Mustafa, U. (2012). External Debt Accumulation and Its Impact on Economic Growth in Pakistan. The Pakistan Development Review, 79-95.

[37]. Shabbir, S. (2005). Does External Debt Affect Economic Growth: Evidence from Developing Countries? Un-published paper.

[38]. Singh, C. (1999). Domestic Debt and Economic Growth in India. Economic and Political Weekly, 34, 1445-1453. 
[39]. Umaru, A., Hamidu, A. A., \& Musa, S. (2013). External Debt and Domestic Debt Impact on the growth of the Nigerian Economy. International Educational Research, 70-86.

[40]. Were, M. (2001). The Impact of External Debt on Economic Growth in Egypt. Discussion Paper No. 2001/116. World Institute for Development Economic Research. Helsinki: United Nations University.

[41]. Zhang, J. W., \& Wang, S. (2012). Financial development and economic growth: evidence from China. Hongkong: Hong Kong University of Science and Technology.

[42] Stella Spilioti "The relationship between the government debt and GDP growth: evidence of the Euro area countries"

[43] K.M. Ting \& R.J.Y. Quek "Model stability: a key factor in determining whether an algorithm produces an optimal model from a matching distribution "

Websites

https://en.wikipedia.org/wiki/Regression diagnostic

https://www.statisticshowto.datasciencecentral.com/serial-correlation-

autocorrelation/ https://www.investopedia.com/terms/h/heteroskedasticity.asp

https://en.wikipedia.org/wiki/Normality_test

https://en.wikipedia.org/wiki/Jarque\% E2\% 80\%93Bera_test

https://www.ibm.com/support/knowledgecenter/en/SS3RA7_15.0.0/com.ibm.sp

ss.modeler. help/tim eseries acf pacf.htm

https://www.statisticshowto.datasciencecentral.com/statistical-stability/ 


\section{APPENDIXES}

\section{Appendix (1)}

WEOApr2019all file and Gross-debt-as-Percentage-of-GDP are both available on the international monetary fund website :

https://www.imf.org/external/datamapper/index.php

\section{Appendix (2)}

Null Hypothesis: GDP_B has a unit root

Exogenous: Constant, Linear Trend

Lag Length: 4 (Automatic - based on SIC, maxlag=9)

\begin{tabular}{llll}
\hline \hline & t-Statistic & Prob.* \\
\hline \hline $\begin{array}{l}\text { Augmented Dickey-Fuller test } \\
\text { statistic }\end{array}$ & -0.408840 & $\mathbf{0 . 9 8 3 0}$ \\
\hline Test critical & & & \\
values: & $1 \%$ level & -4.262735 & \\
& $5 \%$ level & -3.552973 & \\
& $10 \%$ level & -3.209642 & \\
& & & \\
\hline \hline
\end{tabular}

*MacKinnon (1996) one-sided p-values.

Appendix (3)

Null Hypothesis: GGD_B has a unit root

Exogenous: Constant, Linear Trend

Lag Length: 1 (Automatic - based on SIC, maxlag=9)

\begin{tabular}{lccc}
\hline \hline & t-Statistic & Prob.* \\
\hline \hline \multicolumn{2}{c}{ Augmented Dickey-Fuller test } \\
statistic & $-\mathbf{0 . 3 6 4 4 5 6}$ & $\mathbf{0 . 9 8 5 2}$ \\
\hline Test critical & & & \\
values: & 1\% level & -4.234972 & \\
& $5 \%$ level & -3.540328 & \\
& $10 \%$ level & -3.202445 & \\
\hline \hline
\end{tabular}

*MacKinnon (1996) one-sided p-values. 
Appendix (4)

\section{ERRORLR}

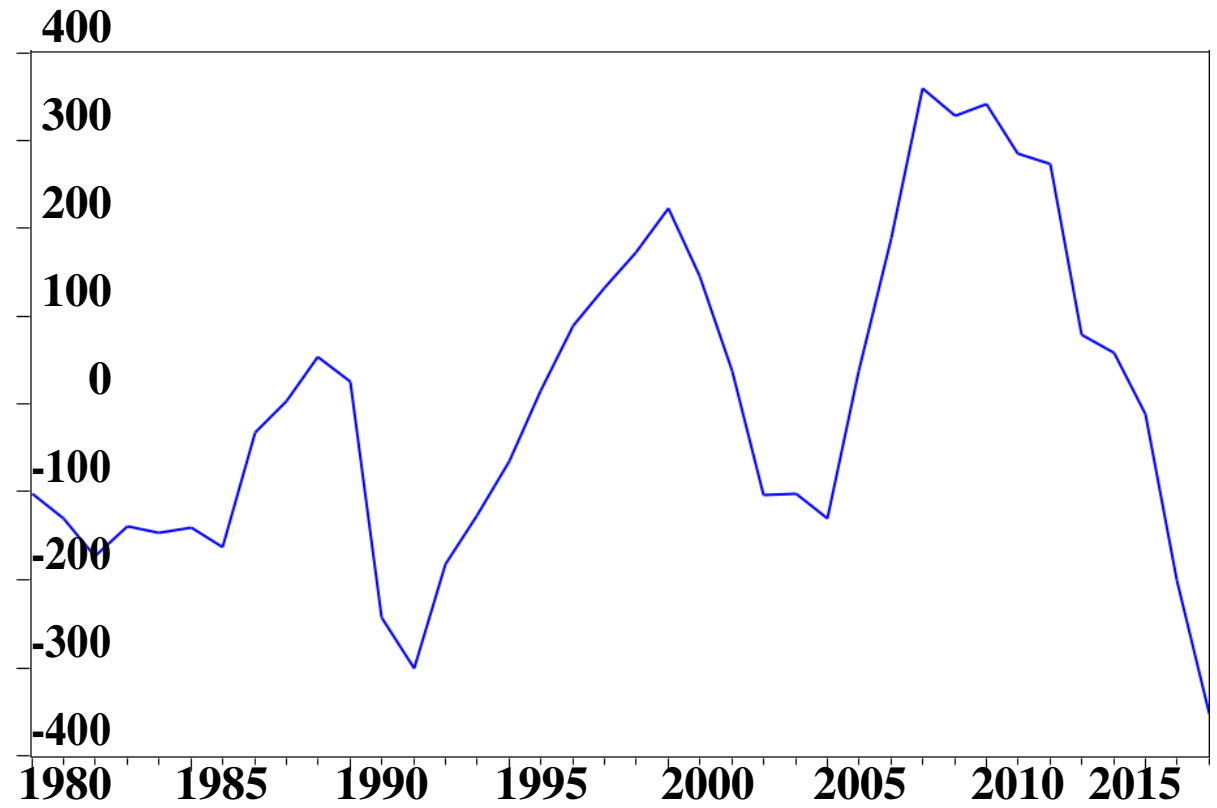

Null Hypothesis: ERRORLR has a unit root

Exogenous: None

Lag Length: 1 (Automatic - based on SIC, maxlag=9)

\begin{tabular}{lccc}
\hline \hline & t-Statistic & Prob.* \\
\hline \hline $\begin{array}{l}\text { Augmented Dickey-Fuller test } \\
\text { statistic }\end{array}$ & -2.478323 & 0.0147 \\
\hline $\begin{array}{l}\text { Test critical } \\
\text { values: }\end{array}$ & $1 \%$ level & $-\mathbf{2 . 6 3 0 7 6 2}$ & \\
& $5 \%$ level & -1.950394 & \\
& $10 \%$ level & -1.611202 & \\
\hline \hline
\end{tabular}

*MacKinnon (1996) one-sided p-values.

Dependent Variable: D(GDP_B)

Method: Least Squares

Date: 06/06/19 Time: 16:33

Sample (adjusted): 19812017

Included observations: 37 after adjustments

\begin{tabular}{cccc}
\hline \hline Varianাe & Coefficient & Std. Error & t-Statistic Prob. \\
\hline \hline ERRORLR (-1) & $\mathbf{0 . 0 4 6 0 8 5}$ & $\mathbf{0 . 0 2 1 8 8 3}$ & $\mathbf{2 . 1 0 5 9 4 9 0 . 0 4 2 5}$ \\
C & $\mathbf{4 3 . 1 0 3 6 7}$ & $\mathbf{3 . 7 9 4 8 3 5}$ & $\mathbf{1 1 . 3 5 8 5 1 0 . 0 0 0 0}$ \\
\hline
\end{tabular}


Although the Error of the linear regression is significant the coefficient of the regression between Error (-1) and D(GDP_B) "The Error Correction Term" is not negative and thus the model will not correct itself on the long-run and VECM will not be used to estimate this relationship

\section{Appendix (5)}

Vector Autoregression Estimates

Sample (adjusted): 19822017

Included observations: 36 after adjustments

Standard errors in () \& t-statistics in []

\begin{tabular}{|c|c|c|}
\hline & GDP_B & GGD_B \\
\hline$\overline{G D P \_B ~(-1)}$ & $\begin{array}{l}\mathbf{1 . 6 0 5 6 7 7} \\
(\mathbf{0 . 1 2 9 4 3 )} \\
{[12.4055]}\end{array}$ & $\begin{array}{l}-0.549379 \\
(0.77056) \\
{[-0.71297]}\end{array}$ \\
\hline GDP_B (-2) & $\begin{array}{l}-\mathbf{0 . 6 2 5 1 4 7} \\
(\mathbf{0 . 1 3 5 5 5}) \\
{[-4.61204]}\end{array}$ & $\begin{array}{l}0.751400 \\
(0.80695) \\
{[0.93116]}\end{array}$ \\
\hline GGD_B (-1) & $\begin{array}{l}-\mathbf{0 . 0 2 4 7 9 7} \\
(\mathbf{0 . 0 3 0 2 7}) \\
{[-\mathbf{0 . 8 1 9 0 5}]}\end{array}$ & $\begin{array}{l}\mathbf{1 . 2 3 5 6 0 2} \\
(\mathbf{0 . 1 8 0 2 4}) \\
{[\mathbf{6 . 8 5 5 4 5}]}\end{array}$ \\
\hline GGD_B (-2) & $\begin{array}{l}\mathbf{0 . 0 7 9 5 4 8} \\
(\mathbf{0 . 0 3 3 4 4}) \\
{[2.37901]}\end{array}$ & $\begin{array}{l}-0.401694 \\
(0.19906) \\
{[-2.01793]}\end{array}$ \\
\hline $\mathrm{C}$ & $\begin{array}{l}-7.869803 \\
(6.66945) \\
{[-1.17998]}\end{array}$ & $\begin{array}{l}\mathbf{3 . 6 2 7 5 8 1} \\
(39.7053) \\
{[0.09136]}\end{array}$ \\
\hline R-squared & 0.999390 & 0.967106 \\
\hline Adj. R-squared & 0.999311 & 0.962862 \\
\hline Sum sq. resids & 4807.557 & 170388.9 \\
\hline S.E. equation & 12.45321 & 74.13783 \\
\hline F-statistic & 12687.47 & 227.8583 \\
\hline Log likelihood & -139.1814 & -203.4035 \\
\hline Akaike AIC & 8.010080 & 11.57797 \\
\hline Schwarz SC & 8.230014 & 11.79791 \\
\hline Mean dependent & 1053.007 & 930.6217 \\
\hline
\end{tabular}


S.D. dependent $\quad \mathbf{4 7 4 . 3 4 8 4} \quad 384.7079$

Determinant resid covariance (dof

adj.)

834867.2

Determinant resid

covariance

619064.3

Log likelihood

$-342.2109$

Akaike information

criterion

19.56727

Schwarz criterion

20.00714

Number of

coefficients

10

Null Hypothesis: RESID has a unit root

Exogenous: Constant

Lag Length: 0 (Automatic - based on SIC, maxlag=9)

\begin{tabular}{lccc}
\hline \hline & t-Statistic & Prob.* \\
\hline \hline $\begin{array}{l}\text { Augmented Dickey-Fuller test } \\
\text { statistic }\end{array}$ & -6.576647 & $\mathbf{0 . 0 0 0 0}$ \\
\hline $\begin{array}{l}\text { Test critical } \\
\text { values: }\end{array}$ & $1 \%$ level & -3.632900 & \\
& $5 \%$ level & -2.948404 & \\
& $10 \%$ level & -2.612874 & \\
& & & \\
\hline
\end{tabular}

\section{Appendix (6)}

Dependent Variable: GGD_B

Method: Least Squares (Gauss-Newton / Marquardt steps)

Sample (adjusted): 19822017

Included observations: 36 after adjustments

GGD_B = C (6) *GDP_B (-1) + C (7) *GDP_B (-2) + C (8) *GGD_B (-1) + C (9)

*GGD_B (-2) + C (10) 


\begin{tabular}{|c|c|c|c|}
\hline & Coefficient & Std. Error t-Statistic & Prob. \\
\hline$C(6)$ & -0.549379 & -0.712965 & 0.4812 \\
\hline C (7) & 0.751400 & $0.806952 \quad 0.931158$ & 0.3590 \\
\hline$C(8)$ & 1.235602 & 6.855448 & 0.0000 \\
\hline C (9) & -0.401694 & $0.199062-2.017933$ & 0.0523 \\
\hline C (10) & 3.627581 & $39.70528 \quad 0.091363$ & 0.9278 \\
\hline R-squared & 0.967106 & \multirow{2}{*}{ Mean dependent var } & 930.6217 \\
\hline $\begin{array}{l}\text { Adjusted R- } \\
\text { squared }\end{array}$ & 0.962862 & & 384.7079 \\
\hline $\begin{array}{l}\text { S.E. of } \\
\text { regression }\end{array}$ & 74.13783 & Akaike info criterion & 11.57797 \\
\hline $\begin{array}{l}\text { Sum squared } \\
\text { resid }\end{array}$ & 170388.9 & \multirow{4}{*}{$\begin{array}{l}\text { Schwarz criterion } \\
\text { Hannan-Quinn criter. } \\
\text { Durbin-Watson stat }\end{array}$} & 11.79791 \\
\hline Log likelihood & -203.4035 & & 11.65474 \\
\hline F-statistic & 227.8583 & & 2.061430 \\
\hline Prob(F-statistic & 0.000000 & & \\
\hline
\end{tabular}

\section{Appendix (7)}

VAR Residual Heteroskedasticity Tests (Levels and Squares)

Sample: 19802017

Included observations: 36

Joint test:

\begin{tabular}{lll}
\hline \hline Chi-sq & df & Prob. \\
\hline \hline 34.58787 & 24 & 0.0748 \\
\hline \hline
\end{tabular}

Individual components:

\begin{tabular}{lclrrr}
\hline \hline Dependent & R-squared & F (8,27) & Prob. & Chi-sq (8) & Prob. \\
\hline \hline res1*res1 & $\mathbf{0 . 3 8 9 3 9 9}$ & $\mathbf{2 . 1 5 2 3 4 3}$ & $\mathbf{0 . 0 6 5 3}$ & $\mathbf{1 4 . 0 1 8 3 7}$ & $\mathbf{0 . 0 8 1 3}$ \\
res2*res2 & $\mathbf{0 . 1 7 3 4 5 4}$ & $\mathbf{0 . 7 0 8 2 5 7}$ & $\mathbf{0 . 6 8 1 9}$ & $\mathbf{6 . 2 4 4 3 4 4}$ & $\mathbf{0 . 6 1 9 9}$ \\
res2*res1 & $\mathbf{0 . 3 2 0 8 4 5}$ & $\mathbf{1 . 5 9 4 4 1 2}$ & $\mathbf{0 . 1 7 3 1}$ & $\mathbf{1 1 . 5 5 0 4 3}$ & $\mathbf{0 . 1 7 2 4}$ \\
\hline \hline
\end{tabular}


Appendix (8)

VAR Residual Serial Correlation LM Tests

Date: 06/05/19 Time: 17:44

Sample: 19802017

Included observations: 36

Null hypothesis: No serial correlation at lag $h$

Lag LRE* stat df Prob. Rao F-stat df Prob.

\begin{tabular}{lllllll}
\hline \hline 1 & 3.425808 & 4 & $\mathbf{0 . 4 8 9 2}$ & $\mathbf{0 . 8 6 7 2 2 6}$ & $(4,56.0)$ & $\mathbf{0 . 4 8 9 4}$ \\
2 & 7.505893 & 4 & $\mathbf{0 . 1 1 1 4}$ & $\mathbf{1 . 9 7 0 4 4 2}$ & $(4,56.0)$ & 0.1116 \\
\hline \hline
\end{tabular}

Null hypothesis: No serial correlation at lags 1 to $h$

\begin{tabular}{lrlrrlr}
\hline \hline Lag & LRE* stat & df & Prob. & Rao F-stat & df & Prob. \\
\hline \hline 1 & $\mathbf{3 . 4 2 5 8 0 8}$ & 4 & $\mathbf{0 . 4 8 9 2}$ & $\mathbf{0 . 8 6 7 2 2 6}$ & $\mathbf{( 4 , 5 6 . 0 )}$ & $\mathbf{0 . 4 8 9 4}$ \\
2 & $\mathbf{9 . 1 4 0 3 3 2}$ & 8 & $\mathbf{0 . 3 3 0 6}$ & $\mathbf{1 . 1 7 5 1 6 7}$ & $\mathbf{( 8 , 5 2 . 0 )}$ & $\mathbf{0 . 3 3 1 8}$ \\
\hline \hline
\end{tabular}

*Edgeworth expansion corrected likelihood ratio statistic.

Appendix (9)

VAR Residual Normality Tests

Orthogonalization: Cholesky (Lutkepohl)

Null Hypothesis: Residuals are multivariate normal

Date: 06/05/19 Time: 17:41

Sample: 19802017

Included observations: 36

\begin{tabular}{llcccc}
\hline \hline Component & Skewness & Chi-sq & df & Prob.* $^{*}$ & \\
\hline \hline 1 & -0.461586 & 1.2783731 & & 0.2582 \\
2 & 0.545705 & 1.7867641 & 0.1813 \\
\hline \hline Joint & & 3.0651372 & 0.2160 \\
\hline \hline
\end{tabular}

\begin{tabular}{lccccc} 
Component & Kurtosis & Chi-sq & df & Prob. & \\
\hline \hline 1 & 4.584946 & 3.7680831 & & $\mathbf{0 . 0 5 2 2}$ \\
2 & $\mathbf{3 . 3 4 3 4 6 6}$ & $\mathbf{0 . 1 7 6 9 5 3 1}$ & & $\mathbf{0 . 6 7 4 0}$ \\
\hline \hline
\end{tabular}


Joint

3.9450362

0.1391

\begin{tabular}{cccc}
\hline \hline Component & $\begin{array}{l}\text { Jarque- } \\
\text { Bera }\end{array}$ & df & Prob. \\
\hline \hline 1 & $\mathbf{5 . 0 4 6 4 5 6}$ & 2 & $\mathbf{0 . 0 8 0 2}$ \\
2 & $\mathbf{1 . 9 6 3 7 1 8}$ & $\mathbf{2}$ & $\mathbf{0 . 3 7 4 6}$ \\
\hline \hline Joint & $\mathbf{7 . 0 1 0 1 7 3}$ & 4 & $\mathbf{0 . 1 3 5 4}$ \\
\hline \hline
\end{tabular}

*Approximate p-values do not account for coefficient estimation.

\section{Appendix (10)}

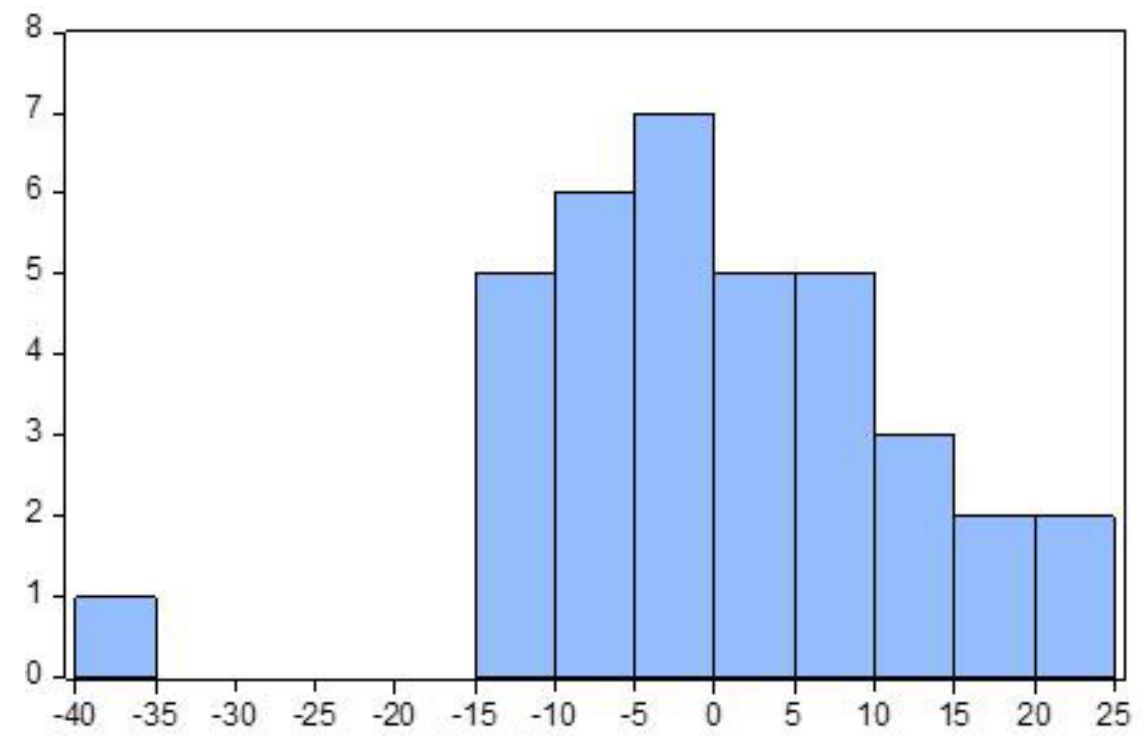

Series: Residuals

Sample 19822017

Observations 36

Mean

$-6.96 \mathrm{e}-13$

Median

$-2.003403$

Maximum

22.27916

Minimum

$-37.94446$

Std. Dev.

11.72002

Skewness $\quad-0.461586$

Kurtosis $\quad 4.584946$

Jarque-Bera $\quad 5.046456$

Probability $\quad 0.080200$ 